comedies. Like many of the papyri found at Kôm Ishgau, the codex seems in places to be very much discoloured, and it is no fault of the photographer that in some pages (for example plate xiii.) very little of the writing comes out legibly in the facsimile; but in many the facsimile can be used with ease, and will serve as a guide to conjecture where the readings are doubtful. It is clear that in his first edition M. Lefebvre, as he now admits, dated the MS. far too early; it may well be of the fifth century. To the facsimile is prefixed a complete transcript, letter for letter and without supplements or division of words, of the whole papyrus, in which use has been made of the work of Croiset, Koerte, Reinach, de Ricci, Jensen, and others. Several new fragments have been found, and in some cases their position determined, since the editio princeps, and these are transcribed in the introduction. M. Lefebvre has also included three other new comic fragments, two of which, clearly of the old Comedy, he assigns to Aristophanes; the third, as it is in the same hand as the others, he also regards, doubtfully, as of the Old Comedy, but the contents seem rather to suggest the New. The MS. from which they come is perhaps of rather earlier date than the Menander codex.

\title{
La Vie Municipale dans l'Égypte Romaine (Bibliotheque des Écoles françaises d'Athènes et de Rome, Fasc. 104me). Par Pierre Jovguet. Pp. xlii + 494. Paris : Fontemoing et Cie. 1911.
}

This important monograph is warmly to be welcomed, and is likely to be for some time the principal authority on the subject which it treats. That subject is even wider than the title would imply; for M. Jouguet has not only devoted seventy pages to a preliminary sketch of municipal life during the Ptolemaic period but within the period more especially chosen for his monograph has dealt with the villages not less than with the Greek cities and Graeco-Egyptian metropoleis. His treatment is indeed admirably complete, and not to be censured on the score of redundancy; for the Roman period can hardly be dissevered from that of the Ptolemies, whose heirs the Romans were, and since the metropoleis were essentially nome-capitals, they can best be studied in conjunction with the villages of the nome. It must be confessed that, in this as in almost every other subject of papyrology, the material is very imperfect-how imperfect, one realizes as soon as one begins to go into detail. It is scantier for the Ptolemaic than for the Roman period, scantier for the Greek city than for the metropolis, for the latter than for the village; and on many subjects of importance any definite conclusion is impossible or, if arrived at, must rest on mere conjecture. On all, however, M. Jouguet writes with the admirable caution and fairness which we expect from him, weighing carefully all the possibilities and never mistaking conjecture for fact. The main outlines of the developement at least are clear ; and it is a study of intense interest to trace the fortunes of Hellenism in Egypt, so dissimilar in many respects to the other Hellenistic kingdoms. How, even in Egypt, where during the Ptolemaic period the Greek ró $\lambda \iota s$ was so imperfectly naturalized, a municipal organization was at length evolved, M. Jouguet shows in his later chapters. It is a curious fact that a real municipal system was only reached by the time when that system was beginning to decay throughout the Empire. One serious complaint must be made against this volume: it has an index of proper names and a table of contents, but it is most regrettable that a work of its importance was not provided with an ample subject-index. 